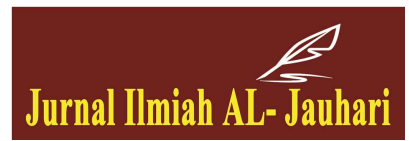

Jurnal Ilmiah ALo-Jauhari: Jurnal Studi Islam dan Interdisipliner

Volume 5 No 1, (April 2020): Halaman 77-98

ISSN (Print): 2541-3430, ISSN (Online): 2541-3449

Website: http://journal.iaingorontalo.ac.id/index.php/aj

\title{
Evaluasi Sistem Pendidikan Multikultural dalam Pengembangan Diri Peserta Didik di SMP Negeri 1 Kota Gorontalo
}

\author{
Manti S. Bempa, Asiah T. Pido \\ (Pascasarjana IAIN Sultan Amai Gorontalo, Dosen IAIN Sultan Amai \\ Gorontalo) \\ mantikbempa123@gmail.com, asiahpido@iaingorontalo.ac.id
}

\begin{abstract}
Multicultural education offers alternatives through strategic applications and educational concepts based on the use of diversity in people's lives, especially students, such as ethnic, cultural, linguistic, religious, and racial diversity. This study aims to describe the evaluation steps of the multicultural education system in the selfdevelopment of students in junior high schools Negeri 1 Gorontalo City. The method used is a qualitative approach, with observation and interview techniques.

The results showed that the steps in evaluating the multicultural education system in student self development used the Countenance Stake evaluation model approach: 1) The initial steps focus on the symptoms or phenomena that were evaluated according to the K'13 Revised 2017; 2) Collect information based on the characteristics of basic competencies in KI-1 and KI-2; 3) Entering the description data in the matrix framework in this case using the assessment format; 4) Process data analysis on a matrix framework using assessment standards; and 5) Make a report about the results of the analysis.
\end{abstract}




\begin{abstract}
Abstrak
Pendidikan multikultural menawarkan satu alternatif melalui penerapan strategis dan konsep pendidikan yang berbasis pada pemanfaatan keragaman dalam kehidupan masyarakat, khususnya yang ada pada peserta didik, seperti keragaman etnis, budaya, bahasa, agama dan ras. Penelitian ini bertujuan untuk mendeskripsikan langkah-langkah evaluasi sistem Pendidikan Multikultural dalam pengembangan diri peserta didik di SMP Negeri 1 Kota Gorontalo. Metode yang digunakan adalah pendekatan kualitatif, dengan teknik observasi dan wawancara.

Hasil penelitian menunjukkan bahwa langkah-langkah evaluasi sistem pendidikan multikultural dalam pengembangan diri peserta didik dengan menggunakan pendekatan model evaluasi Countenance Stake : 1) Langkah awal memusatkan pada gejala atau fenomena yang dievaluasi sesuai K'13 Revisi 2017; 2) Mengumpulkan informasi yang didasarkan pada karakterisitik kompetensi dasar pada KI-1 dan KI-2; 3) Memasukkan data deskripsi pada framework matrik dalam hal ini menggunakan format penilaian; 4) Processing analisis data pada framework matrik menggunakan standar penilaian; dan 5) Membuat laporan hasil analisis.
\end{abstract}

Kata Kunci : Evaluasi, Pendidikan Multikultural, Pengembangan Diri

\title{
Pendahuluan
}

Undang-Undang Nomor 20 Tahun 2003 tentang Sistem Pendidikan Nasional (UUSPN) menegaskan bahwa evaluasi pendidikan adalah kegiatan pengendalian, penjaminan, dan penetapan mutu pendidikan terhadap berbagai komponen pendidikan pada setiap jalur, jenjang, dan jenis pendidikan sebagai bentuk pertanggungjawaban penyelenggaraan pendidikan. ${ }^{1}$ Menurut Maksum dan Ruhendi bahwa evaluasi pendidikan multikultural ditentukan pada penilaian terhadap tingkah laku peserta didik yang meliputi: persepsi, apresiasi, dan tindakan. ${ }^{2}$ Pada Permendikbud Nomor 23 Tahun 2016 tentang Standar Penilaian Pendidikan, dijelaskan bahwa Mekanisme penilaian aspek sikap dilakukan melalui observasi/pengamatan dan

\footnotetext{
${ }^{1}$ Undang-Undang Nomor 2o Tahun 2003, Sistem Pendidikan Nasional, Pasal 57 ayat $1-2$

${ }^{2}$ Maksum A. dan Ruhendi L.Y., Paradigma Pendidikan Universal, (Yogyakarta: IRCSod 2009), h. 192.

78 | Manti S. Bempa
} 
teknik penilaian lain yang relevan, dan pelaporannya menjadi tanggungjawab wali kelas atau guru kelas. ${ }^{3}$

Tujuan utama dari pendidikan multikultural adalah menanamkan sikap empatik, respek, apresiasi, dan empati terhadap penganut agama dan budaya yang berbeda serta mewujudkan sebuah bangsa yang kuat, maju, adil, makmur, dan sejahtera tanpa perbedaan etnik, ras, agama, dan budaya. Sikap memiliki arti yang sangat penting, khususnya dalam menerangkan perubahan sosial dan budaya. ${ }^{4}$

Dalam pengembangan pribadi, memfasilitasi peserta didik bahwa semua budaya setiap etnis sama nilai antar satu dengan yang lain. Sehingga memiliki kepercayaan diri dalam berinteraksi dengan orang lain walaupun berbeda budaya masyarakatnya. Klarifikasi nilai dan sikap, pendidikan mengangkat nilai nilai inti yang berasal dari prinsip martabat manusia, keadilan persamaan, dan demokratis, sehingga pendidikan multikultural membantu peserta didik memahami berbagai konflik yang terjadi dalam masyarakat pluralistik. $^{5}$

Pendidikan multikultural menawarkan satu alternatif melalui penerapan strategis dan konsep pendidikan yang berbasis pada pemanfaatan keragaman yang abadi dalam masyarakat, khususnya yang ada pada peserta didik seperti pada keragaman etnis, budaya, bahasa, agama dan ras, sehingga peserta didik selalu berperilaku humanis, pluralis, dan demokratis.

Pendidikan multikultural yaitu mengembangkan sikap mengakui, menerima dan menghargai keragaman, dengan nilai toleransi, empati, simpati, dan solidaritas sosial. ${ }^{6}$ Sikap menerima, mengakui dan menghargai keragaman sangat penting bagi peserta didik yang beranekaragam.

Guru sebagai evaluator harus berperan untuk mengumpulkan data atau informasi sejauhmana perkembangan peserta didik, tidak cukup hanya didukung oleh perencanaan pembelajaran, kemampuan guru mengembangkan proses pembelajaran serta penguasaannya terhadap bahan ajar, tanpa diimbangi dengan kemampuan melakukan evaluasi terhadap perkembangan peserta didik, khususnya sikap VI pasal 9.

${ }^{3}$ Permendikbud Nomor 23 Tahun 2016, Standar Penilaian Pendidikan, bab

${ }^{4}$ Munirah, Nilda S. Ladiku, Pengembagan Sikap Keberagamaan Peserta Didik, "Al-Jauhari" Jurnal Studi Islam dan Interdisipliner Volume 4 No 2,

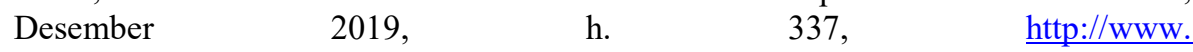
journal.iaingorontalo.ac.id/index.php/aj/article/view/1143/881, diakses 13-01-2020.

${ }^{5}$ Hasbuulah, Dasar Dasar Ilmu Pendidikan,(Jakarta: Rajawali, 2009), h.60.

${ }^{6}$ Abdullah Aly, Pendidikan Multikultural di Pasantren, (Yogyakarta: Pustaka. Pelajar, 2011), h. 124. 
peserta didik yang dapat menerima, mengakui dan menghargai keragaman, sehingga terjalin hubungan baik antar peserta didik, pendidik dan peserta didik, serta peserta didik dengan lingkungan sosial yang harmonis.

\section{Model Evaluasi Sistem Pendidikan}

Menurut bahasa, kata evaluasi berasal dari bahasa Inggris "evalution", yang berarti penilaian atau penaksiran. Sedangkan menurut pengertian istilah evaluasi merupakan kegiatan yang terencana untuk mengetahui keadaan sesuatu obyek dengan menggunakan intrument dan hasilnya dibandingkan dengan tolak ukur memperoleh kesimpulan. ${ }^{7}$

Evaluasi merupakan salah satu rangkaian kegiatan dalam meningkatkan kualitas, kinerja, atau produktivitas suatu lembaga dalam melaksanakan programnya. Melalui evaluasi akan diperoleh tentang apa yang telah dicapai dan mana yang belum, dan selanjutnya informasi ini digunakan untuk perbaikan suatu program. ${ }^{8}$

Menurut Cronbach di dalam bukunya Designing Evalutor Of Education and Social Program, telah memberikan uraian tentang prinsip-prinsip dasar evaluasi antara lain :

a) Evaluasi program pendidikan merupakan kegiatan yang dapat membantu pemerintah dalam mencapai tujuannya.

b) Evaluasi seyogyanya tidak memberikan jawaban terhadap suatu pertanyaan khusus. Bukanlah tugas evalutor memberikan rekomendasi tentang kemanfaatan suatu program dan dilanjutkan atau tidak. Evaluator tidak dapat memberikan pertimbangan kepada pihak lain, seperti halnya seorang pembimbing tidak dapat memilihkan karier seorang peserta didik. Tugas evaluator hanya memberikan alternatif.

c) Evaluasi merupakan suatu proses terus menerus, sehingga di dalam proses di dalamnya memungkinkan untuk merevisi apabila dirasakan ada suatu kesalahan-kesalahan. ${ }^{9}$

Ada beberapa model evaluasi yang dikenal dan digunakan untuk mengevaluasi dibidang pendidikan, diantaranya: Model CIPP dikembangkan oleh Daniel Stufflebeam.CIPP merupakan singkatan

${ }^{7}$ M. Chabib Thaha, Teknik Evaluasi Pendidikan, (Raja Grafindo Persada, 1983), h, 220.

${ }^{8}$ Djemari Mardapi, Pengukuran, Penilaian, dan Evaluasi Pendidikan, h. 4.

${ }^{9}$ Daryanto, Evaluasi Pendidikan, ( Jakarta : Rineka Cipta, 2012), h. 2. 
dari Context, Input, Process, dan Product. ${ }^{10}$ CIPP merupakan sebuah model evaluasi yang menggunakan pendekatan yang berorientasi pada manajemen (management-oriented evaluation approach) atau disebut sebagai bentuk evaluasi manajemen program (evaluation in program management $)^{11}$. Madaus dalam Ihwan Mahmudi menjelaskan bahwa model CIPP berpijak pada pandangan bahwa tujuan terpenting dari evaluasi program bukanlah membuktikan (to prove), melainkan meningkatkan (to improve). ${ }^{12}$ Evaluasi context yang menghasilkan informasi mengenai macam-macam kebutuhan yang telah diatur prioritasnya. Evaluasi input, menyediakan informasi tentang masukan yang terpilih, butir-butir kekuatan dan kelemahan, strategi,dan desain untuk merealisasikan tujuan. Evaluasi process, menyediakan informasi untuk para evaluator melakukan prosedur monitoring terpilih yang mungkin baru diimplementasikan. Evaluasi product, mengakomodasi informasi untuk meyakinkan dalam kondisi apa tujuan dapat dicapai. ${ }^{13}$

Evaluasi konteks (context) dimaksud untuk menilai kebutuhan, masalah, asset dan peluang guna membantu pembuat kebijakan menetapkan tujuan dan prioritas. Serta membantu kelompok mengguna lainya untuk mengetahui tujuan, peluang dan hasinya. Evaluasi masukan (input) dilaksanakan untuk menilai alternative pendekatan, rencana tindak, rencana staf dan pembiayaan bagi kelangsungan program dalam memenuhi kebutuhan kelompok sasarn serta mencapai tujuan yang ditetapkan.

Evaluasi ini berguna bagi pembuat kebijakan untuk memilih rancangan, bentuk pembiayaan, alokasi sumber daya, pelaksana dan jadual kegiatan yang sesuai bagi kelangsungan program. Evalusi proses (process) ditujukan untuk menilai implementasi dari rencana yang telah ditetapkan guna membantu para pelaksana dalam menjalankan kegiatan dan kemudian akan dapat membantu kelompok pengguna lainnya untuk mengetahui program kerja dan memperkirakan hasilnya. Evaluasi hasil (product) dilakukan dengan tujuan untuk mengidentifikasi dan menilai hasil yang dicapai-yang diharapkan dan tidak diharapkan, jangka pendek dan jangka panjang,

10 Nana Syaodih Sukmadinata. Pengembangan Kurikulum Teori dan Praktek. (Bandung: Remaja Rosda Karya 2006), h.8.

${ }^{11}$ John M.Owen, Program Evaluasi: Forms and Approaches. (St. Leonards: Allen \& Unwin Pty Ltd, 1993), h. 21.

${ }^{12}$ Ihwan Mahmudi, CIPP Suatu Model Evaluasi Program Pendidikan, Jurnal, Unida Gontor, Vol. 6, No. 1, Juni 2011, h. 9.

13 Nana Syaodih Sukmadinata. Pengembangan Kurikulum Teori dan Praktek, h. 9. 
baik bagi pelaksana kegiatan agar dapat memfokuskan diri dalam mencapai sasaran program maupun bagi pengguna lainnya dalam menghimpun upaya untuk memenuhi kebutuhan kelompok sasaran.

Model-model evaluasi yang diuraikan di atas, mempunyai persamaan dan juga perbedaan. Model CIPP dapat dilakukan ketika program belum dimulai dan selama program berlangsung. Model Countenance, evaluator sangat disarankan untuk melakukan evaluasi selama program berlangsung. Model formatif dilaksanakan pada setiap kali satuan pembelajaran sedangkan sumatif dilaksanakan setelah seluruh unit pelajaran selesai diajarkan. Model Kirkpatrick mengevaluasi perubahan sikap, perbaikan pengetahuan, maupun peningkatan keterampilan, Sedangkan discrepancy model dilakukan dengan maksud untuk mengetahui tingkat kesesuaian standar yang ingin dicapai dengan program. Model Brinkerhoff menggabungkan elemen-elemen yang sama. Letak keseamaan model-model evaluasi tersebut berorientasi pada peningkatan program.

\section{Konsep Pendidikan Multikultural}

Menurut Herson Anwar bahwa pendidikan multikultural adalah sebuah konsep pendidikan yang menjunjung nilai-nilai "keindonesiaan" yang dalam hal ini, terus menjaga serta mampu melestarikan sosio-kultural bangsa indonesia itu sendiri. ${ }^{14}$

Istilah pendidikan multikultural dapat digunakan pada tingkat deskriptif dan normative, yang menggambarkan isu-isu dan masalahmasalah pendidikan berkaitan dengan masyarakat multikultural. Lebih jauh lagi mencakup pengertian tentang pertimbangan terhadap kebijakan-kebijakan dan strategi-strategi pendidikan dalam masyarakat multikultural. Dalam konteks deskriptif ini, maka kurikulum pendidikan multkultural harus mencakup subjek-subjek seperti : toleransi, tema-tema tentang perbedaan etno-kultural, dan agama; bahaya diskriminasi; penyelesaian konflik dan mediasi; HAM; demokrasi dan pluralitas; kemanusiaan universal dan subjek-subjek lain yang relevan. ${ }^{15}$

Sebagai sebuah ideologi, multikulturalisme terserap dalam berbagai interaksi yang ada dalam berbagai struktur kegiatan kehidupan manusia yang tercakup dalam kehidupan sosial, kehidupan

\footnotetext{
${ }^{14}$ Herson Anwar, Pendidikan Multikultural (Tinjauan Manajemen Lembaga Pendidikan Islam Pesantren dan Madrasah), Irfani Jurnal Manajemen Pendidikan Islam Volume $12 \quad$ Nomor 1 Juni 2016, http://journal.iaingorontalo.ac.id/index.php/ir/article/view/457, diakses 13-01-2020.

${ }^{15}$ Agil, Said.s Aktualisasi Nilai-nilai Qur'ani dalam Sistem Pendidikan Islam .(Jakarta Selatan: Ciputat Press, 2004), h. 80. 
ekonomi dan bisnis, dan kehidupan politik, dan berbagai kegiatan lainnya di dalam masyarakat yang bersangkutan. Interaksi tersebut berakibat pada terjadinya perbedaan pemahaman tentang multikulturalisme. Lebih jauh, perbedaan ini berimplikasi pada perbedaan sikap dan perilaku dalam menghadapi kondisi multikultural masyarakat. Sebagai sebuah ideologi, multikulturalisme harus diperjuangkan, karena dibutuhkan sebagai landasan bagi tegaknya demokrasi, hak asasi manusia dan kesejahteraan hidup masyarakatnya. ${ }^{16}$

Pendidikan Multikultural, adalah merupakan keinginan untuk mengeksplorasi perbedaan sebagai sebuah keniscyaan (anugerah Tuhan/sunatullah). ${ }^{17}$

Pentingnya hidup berdampingan dalam bingkai persamaan dan kasih sayang telah Allah SWT Firmankan dalam Al-Qur'an Surat AlHujurat Ayat 13.

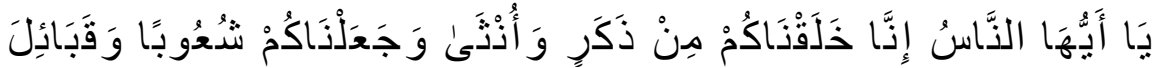

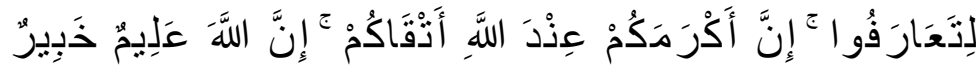

Terjemahnya :

Hai manusia, sesungguhnya Kami menciptakan kamu dari seorang laki-laki dan seorang perempuan dan menjadikan kamu berbangsa-bangsa dan bersuku-suku supaya kamu saling kenalmengenal. Sesungguhnya orang yang paling mulia diantara kamu disisi Allah ialah orang yang paling takwa diantara kamu. Sesungguhnya Allah Maha Mengetahui lagi Maha Mengenal. ${ }^{18}$

Dari ayat di atas, dapat dipahami, bahwa hidup dalam keberagaman dengan damai tanpa memandang status sosial, ras, agama, etnis, dan budaya, telah Allah SWT perintahkan jauh sebelumnya, oleh karenanya, sebagai bangsa yang beragama, hendaknya memahami substansi ayat ini dalam mewujudkan kerukunan hidup dalam bingkai pluralisme.

Tujuan pendidikan dengan berbasis multikultural dapat diidentifikasi:

${ }^{16}$ James Banks, "Multicultural Education: Historical Development, Dimensions, And Practice", Review of Research in Education, 1993, h. 3.lihat http://globallavebook.blogspot. relevansinya.html diakses 20 November 2018

${ }^{17}$ Herson Anwar, Pendidikan Multikultural (Tinjauan Manajemen Lembaga Pendidikan Islam Pesantren dan Madrasah), "Irfani” Jurnal Manajemen Pendidikan Islam Volume 12 Nomor 1 Juni 2016, http://journal.iaingorontalo.ac.id/index.php/ir/article/view/457, diakses 13-01-2020.

${ }^{18}$ Lihat Q.S. Al-Hujurat :13 
a) Untuk memfungsikan peranan sekolah dalam memandang keberadaan peserta didik yang beraneka ragam;

b) Untuk membantu peserta didik dalam membangun perlakuan yang positif terhadap perbedaan kultural, ras, etnik, kelompok keagamaan;

c) Memberikan ketahanan peserta didik dengan cara mengajar mereka dalam mengambil keputusan dan keterampilan sosialnya;

d) Untuk membantu peserta didik dalam membangun ketergantungan lintas budaya dan memberi gambaran positif kepada mereka mengenai perbedaan kelompok. ${ }^{19}$

\section{Evaluasi Sistem Pendidikan Multikultural}

Evaluasi sistem pendidikan multikultural dalam pengembangan diri peserta didik di SMP Negeri 1 Kota Gorontalo menggunakan pendekatan model evaluasi Countenance Stake dengan langkah-langkah sebagai berikut :

\section{Langkah Awal memusatkan pada Gejala atau Fenomena yang dievaluasi}

Sebagaimana diuraikan pada landasan teori bahwa langkah awal model Countenance Stake disesuaikan dengan kurikulum yang berlaku di sekolah. Berdasarkan dokumen Kurikulum SMP Negeri 1 Gorontalo sudah menggunakan K'13 Revisi 2017. K'13 Revisi 2017 membagi kompetensi sikap menjadi 2 yaitu : Kompetensi sikap spiritual mengacu pada KI-1 : Menghargai dan menghayati ajaran agama yang dianutnya dan KI -2 Menunjukkan perilaku jujur, disiplin, tanggungjawab, peduli (toleransi, gotong royong), santun, percaya diri, dalam berinteraksi secara efektif dengan lingkungan sosial dan alam dalam jangkauan pergaulan dan keberadaannya. ${ }^{20}$

\section{Mengumpulkan informasi}

Untuk mengumpulkan informasi tentang sistem pendidikan multikultural dalam pengembangan diri peserta didik di SMP Negeri 1 Gorontalo sebagai perluasan cakupan penilaian sikap. didasarkan pada karakterisitik kompetensi dasar pada KI-1 dan KI-2 setiap mata pelajaran.

${ }^{19}$ D.J. Skeel, Elementary Social Studies: Challenge for Tomorrow's World (New York: Harcount Brce College Publishers, 1995), hlm. 76.

${ }^{20}$ Dokumen Kurikulum SMP Negeri 1 Gorontalo, 08-01-2020 
Berdasarkan dokumen Kurikulum SMP Negeri 1 Gorontalo bahwa acuan perumusan Indikator Sikap (KI-1 dan KI-2) dalam penyusunan RPP, sebagai berikut :

\begin{tabular}{|c|c|}
\hline $\begin{array}{c}\text { KI-1 } \\
\text { SIKAP SPIRITUAL }\end{array}$ & $\begin{array}{c}\text { KI-2 } \\
\text { SIKAP SOSIAL }\end{array}$ \\
\hline 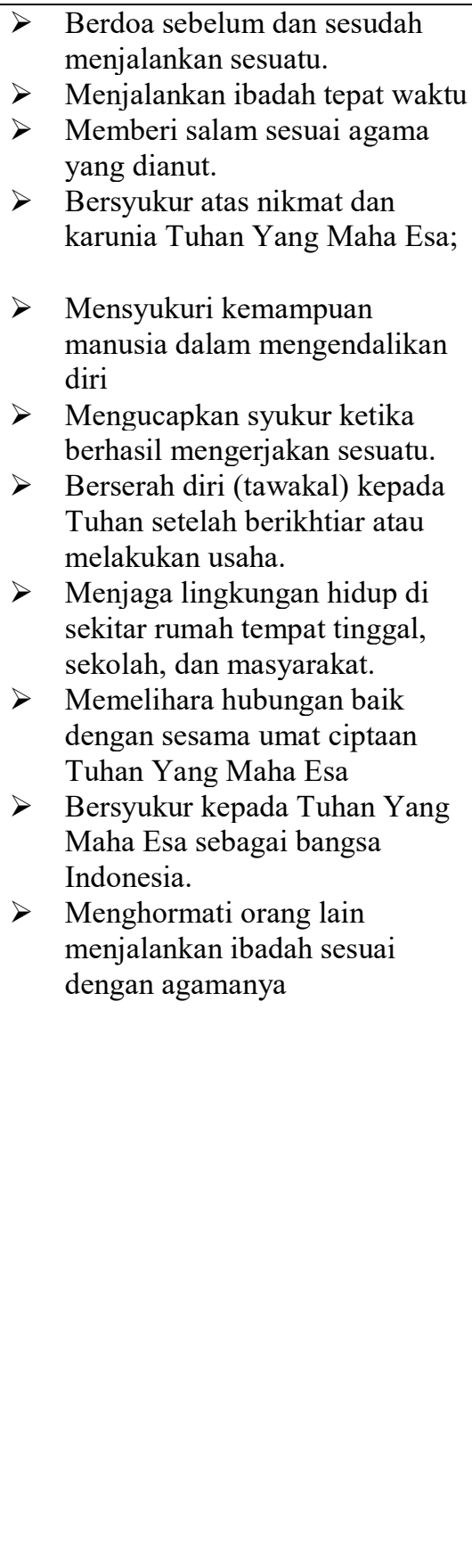 & 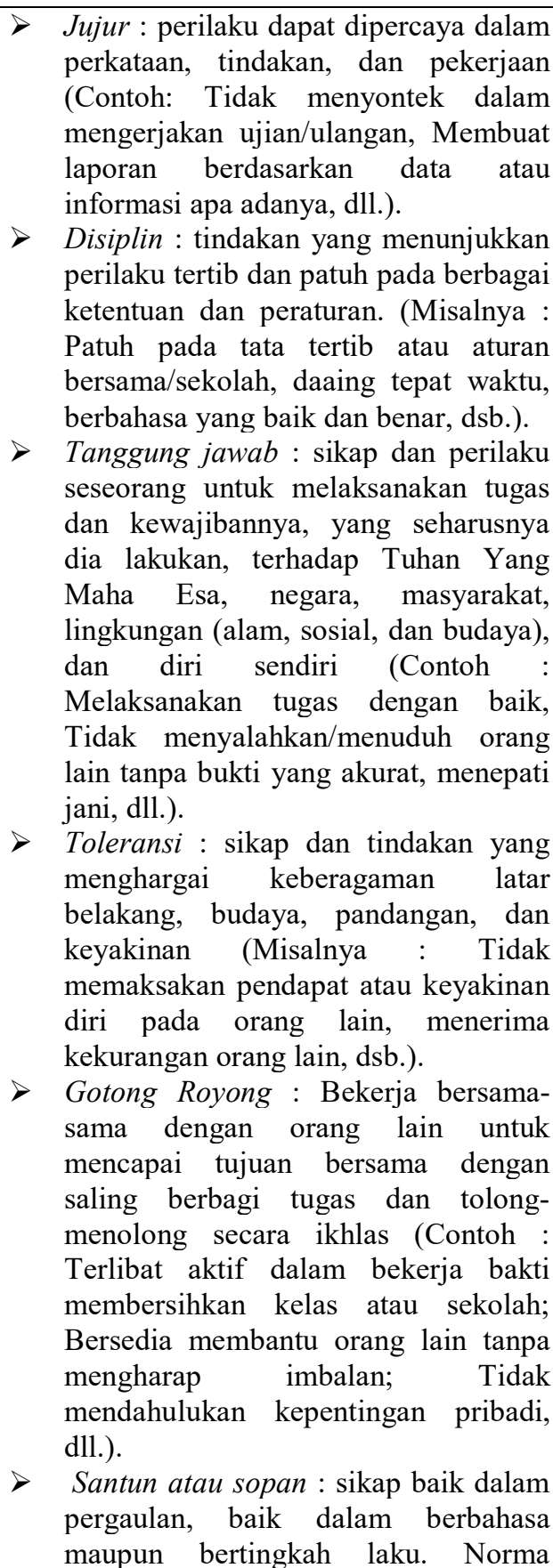 \\
\hline
\end{tabular}

Jurnal Ilmiah AL-Jauhari Vol. 5 No. 1 (2020): 77-98 


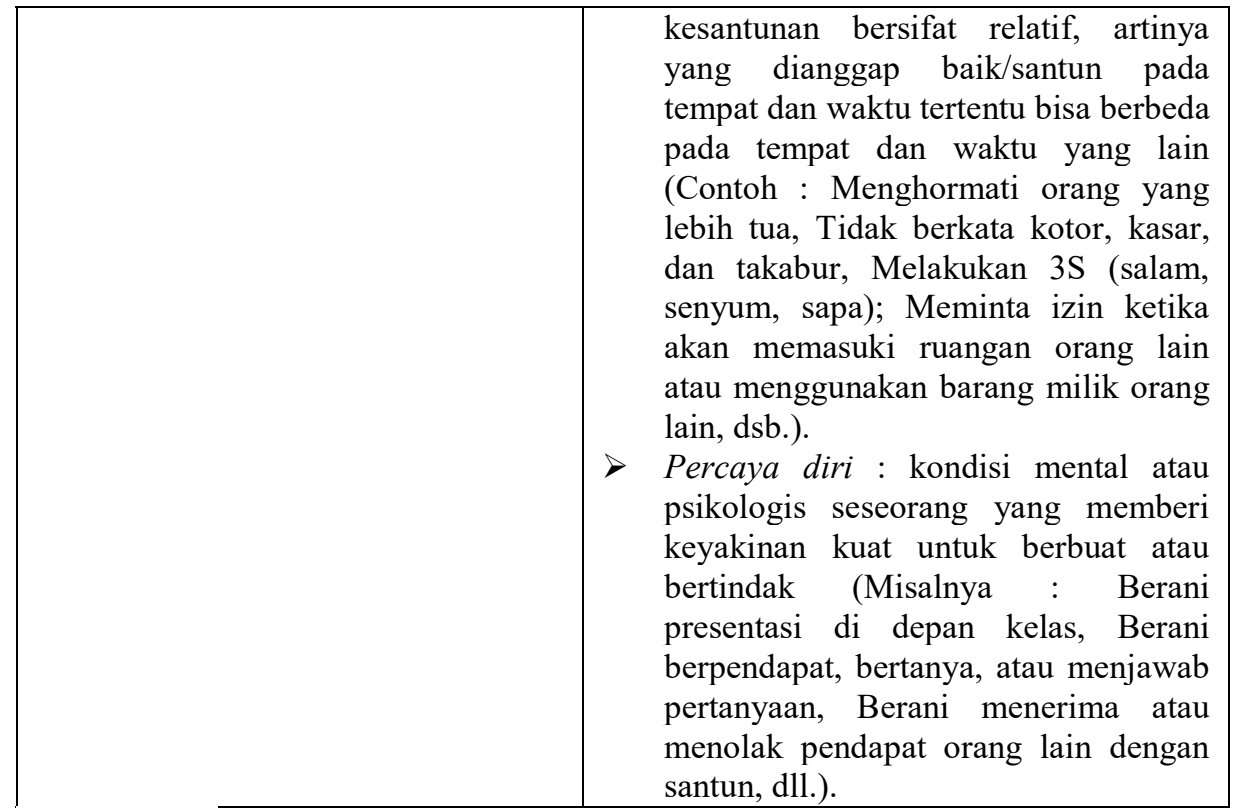

Sumber data : Dokumen Kurikulum SMP Negeri 1 Gorontalo, 08-01-2020

\section{Memasukkan Data Deskripsi pada Framework Matrik}

Pada tahap ini evaluator memasukkan informasi data deskripsi

ke format penilaian sebagai berikut :

a. Hubungan antar sesama peserta didik

Instrumen yang digunakan dalam penilaian hubungan antar sesama peserta didik di SMP Negeri 1 Kota Gorontalo, menggunakan format penilaian antar teman sesuai kurikulum 2013, sebagai berikut :

Nama teman yang dinilai :

Nama penilai

Kelas

Semester

Petunjuk: Berilah tanda centang $(\sqrt{ })$ pada kolom 1 (tidak pernah), 2 (kadang-kadang), 3 (sering), atau 4 (selalu) sesuai dengan keadaan teman kalian yang sebenarnya.

\begin{tabular}{clllll}
\hline No. & \multicolumn{1}{c}{ Pernyataan } & 1 & 2 & 3 & 4 \\
\hline 1. & $\begin{array}{l}\text { Teman saya memberi salam } \\
\text { ketika bertemu sesama teman. }\end{array}$ & & & & \\
\hline 2. & $\begin{array}{l}\text { Teman saya saling membantu } \\
\text { membersihkan kelas }\end{array}$ & & & \\
\hline 3. & $\begin{array}{l}\text { Teman saya tidak mengganggu } \\
\text { teman yang beragama lain } \\
\text { berdoa sesuai agamanya }\end{array}$ \\
\end{tabular}


4. Teman saya tidak mengganggu teman yang beragama lain melakukan ibadah sesuai agama dan kepercayaannya.

5. Teman saya menghormati teman yang berbeda suku, agama, ras, budaya, dan jenis kelamin

6. Teman saya bekerja sama menyelesaikan tugas kelompok

7. Teman saya suka tolong menolong sesama teman yang kesulitan atau mendapat musibah.

8. Teman saya menghargai pendapat teman yang lain

\begin{tabular}{ll}
\hline 9. & Teman saya menyumbangkan \\
tenaga ataupun materi dalam \\
memeriahkan kegiatan \\
keagamaan di sekolah.
\end{tabular}

Sumber data : Dokumen Kurikulum SMP Negeri 1 Gorontalo, 20-12-2019

Keterangan : 4 = Apabila selalu melakukan sesuai pernyataan

3 = Apabila sering melakukan sesuai pernyataan dan kadang-kadang tidak melakukan

$$
\begin{aligned}
& 2=\text { Apabila kadang-kadang melakukan dan sering } \\
& \text { tidak melakukan } \\
& 1=\text { Apabila tidak pernah melakukan }
\end{aligned}
$$

b. Hubungan Pendidik dan Peserta Didik

Instrumen yang digunakan dalam penilaian hubungan Pendidik dan Peserta Didik di SMP Negeri 1 Kota Gorontalo, menggunakan format penilaian observasi/pengamatan dari guru sebagai berikut:

\begin{tabular}{|c|c|c|c|c|c|c|}
\hline No. & \multicolumn{4}{|c|}{ Indikator Sikap } & \multicolumn{4}{|c|}{ Nilai Sikap } & \multirow{2}{*}{ Deskripsi } \\
\cline { 3 - 6 } & & SB & B & C & K & \\
\hline 1. & Memberi salam kepada guru & & & & & \\
\hline 2. & Mendengarkan guru yang sedang berbicara & & & & & \\
\hline
\end{tabular}




\begin{tabular}{|c|l|c|c|c|c|c|}
\hline 3. & $\begin{array}{l}\text { Menyampaikan/mengutarakan pendapat } \\
\text { dengan baik dan sopan }\end{array}$ & & & & \\
\hline 4. & $\begin{array}{l}\text { Bersedia membantu guru tanpa mengharap } \\
\text { imbalan }\end{array}$ & & & & \\
\hline 5. & $\begin{array}{l}\text { Besedia melakukan tugas yang } \\
\text { diperintahkan guru }\end{array}$ & & & & \\
\hline 6. & Tidak memotong pembicaraan guru & & & & & \\
\hline 7. & $\begin{array}{l}\text { Meminta izin ketika akan memasuki atau } \\
\text { keluar ruang guru/kelas }\end{array}$ & & & & & \\
\hline 8. & $\begin{array}{l}\text { Membantu guru baik tenaga ataupun } \\
\text { materi dalam memeriahkan kegiatan } \\
\text { sekolah }\end{array}$ & & & & & \\
\hline 9. & dll. & & & & & \\
\hline
\end{tabular}

Sumber data : Dokumen Kurikulum SMP Negeri 1 Gorontalo, 20-12-2019

Keterangan :

1) $\mathrm{SB}($ Sangat Baik $)=$ Selalu menunjukkan aspek yang dinyatakan dalam indikator

2) $B$ (Baik) = Sering menunjukkan aspek yang dinyatakan dalam indikator

3) $\mathrm{C}$ (Cukup) $=$ Kadang-kadang menunjukkan aspek yang dinyatakan dalam indikator

4) $\mathrm{K}$ (Kurang) $=$ Tidak menunjukkan aspek yang dinyatakan dalam indicator

\section{c. Hubungan dengan Peserta Didik dan Lingkungan Sosial}

Instrumen yang digunakan dalam penilaian hubungan Peserta

Didik dan Lingkungan Sosial di SMP Negeri 1 Kota Gorontalo, menggunakan format penilaian observasi/pengamatan sebagai berikut:

\begin{tabular}{|c|l|c|c|c|c|c|}
\hline No. & \multicolumn{1}{|c|}{ Indikator Sikap } & \multicolumn{3}{|c|}{ Nilai Sikap } & \multirow{2}{*}{ Deskripsi } \\
\cline { 3 - 5 } & & SB & B & C & K & \\
\hline 1. & Bersikap 3S (Salam, senyum, Sapa) & & & & & \\
\hline 2. & Mematuhi tata tertib sekolah & & & & & \\
\hline 3. & Terlibat aktif dalam kegiatan sekolah & & & & & \\
\hline 4. & Membersihkan kelas & & & & & \\
\hline 5. & Membuang sampah pada tempatnya & & & & & \\
\hline 6. & $\begin{array}{l}\text { Merawat sarana atau barang-barang yang } \\
\text { ada di dalam kelas }\end{array}$ & & & & & \\
\hline 7. & Turut serta merawat taman sekolah & & & & & \\
\hline 8. & Bekerja bakti pada kegiatan Jumat bersih & & & & & \\
\hline 9. & $\begin{array}{l}\text { Membantu ketika ada yang terkena musibah } \\
\text { baik guru ataupun peserta didik tanpa } \\
\text { melihat suku, agama, ras, budaya, dan jenis } \\
\text { kelamin }\end{array}$ & & & & & \\
\hline 10. & dll. & & & & \\
\hline
\end{tabular}

Sumber data : Dokumen Kurikulum SMP Negeri 1 Gorontalo, 20-12-2019

Keterangan :

1) SB (Sangat Baik) = Selalu menunjukkan aspek yang 
dinyatakan dalam indikator

2) $\mathrm{B}($ Baik $)=$ Sering menunjukkan aspek yang dinyatakan dalam indikator

3) $\mathrm{C}$ (Cukup) = Kadang-kadang menunjukkan aspek yang dinyatakan dalam indikator

4) $\mathrm{K}$ (Kurang) = Tidak menunjukkan aspek yang dinyatakan dalam indikator

\section{Processing analisis data pada framework matrik}

Tahap ini evaluator membuat standar penilaian untuk menganalisis data sesuai format penilaian yang dilaksanakan. Contoh kriteria penilaian sebagai berikut:

Perhitungan nilai akhir : $\quad \frac{\text { Skor } \text { Perolehan }}{\text { Skor Tertinggi }} \times 100 \%=$

Nilai Akhir

$$
\begin{array}{ll}
\text { Kriteria : } & A=86-100 \quad \text { Baik Sekali } \\
& B=71-85 \quad \text { Baik } \\
& C=60-70 \quad \text { Cukup } \\
& K=59 \text { kebawah } \\
& \text { Kurang. }{ }^{21}
\end{array}
$$

\section{Membuat Laporan Hasil Analisis}

Dalam pendidikan multikultural, SMP Negeri I Kota Gorotalo sebagai lembaga pendidikan harus merancang, merencanakan, dan mengontrol seluruh elemen sekolah yang dapat mendukung proses pendidikan multikultural dengan baik. Sekolah harus merencanakan proses pembelajaran yang dapat menumbuhkan sikap multikultur peserta didik yang menghargai perbedaan, menghargai hak asasi manusia dan keadilan. Sekolah harus mendesain pembelajaran, merancang kurikulum, sistem evaluasi, serta mempersiapkan pendidik yang memiliki perserpsi, sikap dan perilaku multikultural, sehingga menjadi bagian yang memberikan kontribusi positif terhadap pembinaan sikap multikultural para peserta didiknya.

\section{Tenaga Pendidik yang Profesional}

Di Indonesia sebagian besar belum menerapkan pendidikan multikultural sebagaimana mestinya, oleh karena itu pendidik perlu memahami langkah-langkah penting dalam penerapan pendidikan multikultural. Sebelum melangkah atau menerapkan pembelajaran

\footnotetext{
${ }^{21}$ Dokumen RPP Mata Pelajaran Pendidikan Agama Islam \& Budi Pekerti SMP Negeri 1 Gorontalo, 08-01-2020.
} 
multikultural hendaknya pendidik memahami apa tujuan pendidikan multicultural.

Pendidik menjadi bagian yang penting dalam mengembangkan pendidikan multikultural. Pendidik adalah profesi yang mulia. Karena pendidiklah yang membentuk karakter, kedisiplinan, cinta dan kasih sayang terhadap sesama.

Sebagaimana wawancara dengan kepala sekolah menyatakan bahwa tenaga pendidik adalah ujung tombak penentu keberhasilan, berhasil tidaknya sebuah proses pendidikan serta Perubahan perilaku peserta didik dipengaruhi oleh latar belakang pendidikan dan pengalaman yang dimiliki seorang tenaga pendidik. Dengan kata lain, baik dan buruknya seorang peserta didik tidak bisa terlepas dari kualitas pendidik tersebut, saya selaku kepala sekolah senantiasa menghimbau kepada seluruh pendidik untuk selalu memberikan yang terbaik dalam proses belajar mengajar di kelas, dan umumnya di sekolah ini. Selain bekal keilmuan yang cukup, metodologi yang digunakan tenaga pendidik dalam mengajar harus juga diperhatikan, tenaga pendidik harus mampu menyesuaikan metode pembelajaran sesuai dengan perkembangan zaman. Dengan kata lain, selain menjadi pengajar, pendidik juga menjadi researcher. ${ }^{22}$

Wakil kepala sekolah menambahkan pada sesi wawancara dengan peneliti, beliau mengatakan bahwa pendidik yang baik adalah yang mampu mendidik peserta didik menjadi generasi yang mampu bersaing dan memiliki moral yang baik, seorang pendidik hendaknya memiliki perilaku yang baik yang mampu menjadi teladan diikuti oleh peserta didik, lebih dari itu untuk menjadi pendidik yang profesional haruslah memiliki kemampuan dan keahlian dibidang pendidikan, tidak sebatas memiliki kualifikasi pendidikan yang tinggi, akan tetapi harus menguasai metode dan strategi maupun teknik pembelajaran serta memahami landasan kependidikan. sebab di SMP Negeri 1 Kota Gorontalo peserta didik sangat majemuk dan plural,terdiri dari berbagai suku,etnis, ras,agama dan budaya yang berbeda beda. Oleh karenanya tenaga Pendidik harus menjadi sosok yang bijak dalam mengakomodir semua perbedaan yang ada. Di dalam kelas terdapat berbagai macam peserta didik yang berbeda agama, sehingga pendidik harus mampu menjadi asimilator untuk menyatukan perbedaan yang berpotensi menimbulkan perpecahan. Dengan demikian, asimilasi budaya dapat terjadi dalam lingkungan kelas. Dilain sisi pendidik juga harus bertindak sebagai akamodator untuk memfasilitasi semua

\footnotetext{
${ }^{22} \mathrm{Hj}$. Hany Tanua, Kepala Sekolah SMP Negeri I Kota Gorontalo, Wawancara, Tanggal 03 Juli 2019 
peserta didik yang berbeda-beda. Pemahaman kemudian memberikan solusi kearah yang lebih baik. ${ }^{23}$

Dengan adanya perbedaan Agama, suku dan kebudayan pada SMP Negeri 1 Kota Gorontalo, maka pihak sekolah harus mampu mengembangkan nilai-nilai perdamaian, toleransi, hak asasi manusia, demokrasi dan keadilan. Pendidik di sekolah berbasis etnik-agama tertentu sudah seharusnya mengajarkan nilai-nilai kemanusiaan dan keadilan universal yang menjunjung nilai-nilai keadilan dan perdamaian. Misalnya, pada SMP Negeri 1 Kota Gorontalo dengan basis agama tertentu harus mengajarkan kepada peserta didiknya tentang nilai-nilai keagamaan secara universal. Tenaga Pendidik harus menanamkan nilai perdamaian dan keadilan. Mereka harus mengajarkan tidak ada agama dan etnis tertentu yang mengajarkan kekerasan, diskriminasi dan terorisme.

Sebagaimana wawancara dengan salah seorang pendidik mengatakan bahwa sebagai tenaga pendidik kami harus mampu untuk bersikap demokratis, dalam setiap aktifitas, tingkah laku, baik sikap maupun perkataan tidak diskriminatif (bersikap adil dan tidak menyinggung) peserta didik yang berbeda agama. Pembelajaran demokrasi pada hakekatnya adalah untuk mengembangkan eksistensi manusia dengan jalan mengilhaminya dalam tataran martabat dan persamaan, saling mempercayai, toleransi, dan menumbuhkan rasa percaya diri agar peserta didik mampu mengekpresikan apa yang menjadi keinginan mereka, kemudian dari sisi itulah pendidik mengarahkan dan memberi solusi terhadap persoalan yang muncul, sehingga kedepan mereka tidak akan kehilangan arah dan tujuan hidup yang sesungguhnya. Sebagai pendidik harus memiliki sikap dan mental baja dalam mentransper pengetahuan, sebab tidak semua peserta didik merespon dengan baik apa yang disampaikan, maka disitulah profesionalitas kita dituntut, bagaimana mampu merubah suasana pembelajaran yang mulanya statis, berubah menjadi dinamis. $^{24}$

Hal senada juga diungkapkan oleh salah seorang tenaga pendidik bidang kerohanian bahwa sebagai tenaga pendidik harus mempunyai kepekaan dan kepedulian yang tinggi terhadap dinamika yang terjadi, terutama yang berhubungan dengan keyakinan. Saya sebagai pembina kerohanian islam di sekolah ini, tidak pernah memarginalkan peserta didik yang berlainan agama, disaat

\footnotetext{
${ }^{23} \mathrm{Hj}$. Fatmah Kaharu, Waka Sekolah SMP Negeri I Kota Gorontalo, Wawancara, Tanggal 03 Juli 2019

${ }^{24}$ Fransiska Salilama, Guru SMP Negeri 1 Kota Gorontalo, Wawancara, Tanggal 3 Juli 2019
} 
pembelajaran pendidikan agama islam, saya menjelaskan bahwa semua agama sama, mengajarkan tentang ke Esaan yang maha pencipta, tidak ada satupun agama di dunia ini yang mengajarkan tentang kekerasan, sehingga sangat salah ketika diantara sesama tidak saling menyayangi, menghormati dan menghargai antar satu dengan yang lain. Dengan metode ini perlahan tujuan pendidkan multikultural mulai tertanam dalam benak pikiran peserta didik, sehingga kedepan akan tercipta kerukunan, kedamaian, serta ketentraman, bukan hanya di lembaga pendidikan akan tetapi akan berimbas pada kehidupan di luar nanti, baik kehidupan dilingkungan masyarakat maupun berbangsa dan bernegara. ${ }^{25}$

Dari hasil wawancara di atas dapat rumuskan bahwa Peran tenaga pendidik sangat penting untuk menerapkan secara langsung beberapa aksi guna membangun keberagaman peserta didik, tenaga pendidik merupakan faktor penting dalam mengimplementasikan nilai-nilai keberagaman di sekolah serta seorang tenaga pendidik, harus mampu menjelaskan inti dari ajaran agama adalah menciptakan perdamaian dan kesejahteraan bagi seluruh umat manusia. Dialog dan musyawarah adalah cara-cara penyelesaian segala bentuk masalah yang sangat dianjurkan oleh agama dan segala kepercayaan yang ada.

\section{Desain Pembelajaran yang Mendukung}

Desain pembelajaran adalah praktik pemilihan metode atau teknik mentrasper pengetahuan, untuk mendukung terciptanya iklim pendidikan yang harmonis, kondusif, serta edukatif. Karena pendidikan multikultural bukan hanya membina knowledge skill peserta didik, tetapi mendidik menjadikan mereka warga negara yang inklusif, pluralis, demokratis, menghargai hak asasi manusia, dan keadilan.Untuk itu, diperlukan pendidik dan staf sekolah yang memiliki latar belakang pendidikan beragam untuk mewujudkan terciptanya kerukunan antar sesama. Desain pendidikan berbasis nilainilai sosial-multikultural tersebut akan mengintegrasikan tiga tujuan pembelajaran peserta didik, yakni kecerdasan akademik, spiritual, dan sosial.

Sebagaimana wawancara dengan kepala sekolah bahwa ada beberapa hal yang perlu diperhatikan dalam mendesain pembelajaran, diantaranya: Perbedaan budaya dan agama harus memiliki kekuatan nilai, Sekolah harus menjadi model penegakkan HAM dan keadilan, Keadilan dan kesetaraan semua warga sekolah harus menjadi

\footnotetext{
${ }^{25}$ Romy Rauf, Guru SMP Negeri 1 Kota Gorontalo, Wawancara, Tanggal 3 Juli 2019 .

92 | Manti S. Bempa
} 
perhatian yang penting dalam mengembangkan kurikulum, Nilai-nilai demokratis dalam kehidupan masyarakat perlu dipromosikan di sekolah, Lembaga sekolah sebagai tempat untuk mengembangkan kognitif, afektif dan psikomotor peserta didik dari berbagai kelompok yang beragam, Kerjasama guru dengan pihak keluarga dan masyarakat dapat menciptakan lingkungan yang mendukung multikulturalisme. $^{26}$

Dalam setiap desain pembelajaran itu sangat ditentukan oleh kerjasama pendidik, pihak keluarga dan sekolah. Dengan demikian, pendidik menjadi pihak yang terlibat langsung dalam implementasi pendidikan yang multikultur. Metode dan pendekatan pendidik dalam mengajar harus mendukung tegaknya pendidikan multikultural. Oleh sebab itu, pendidik hendaknya menggunakan metode dan pendekatan pembelajaran yang bervariasi.

Sebagaimana wawancara dengan waka bidang kurikulum bahwa tenaga pendidik harus mampu menciptakan suasana pembelajaran yang menyenangkan, mengeksplorasi gaya mengajar yang berbeda beda, untuk mencari benih benih unggul yang ada dalam diri peserta didik. Maka pendidik harus mampu merancang metode pembelajaran yang lebih efektif, misalnya, menyajikan materi dengan cara cara yang baru dan menyenangkan, cara ini akan membuat peserta didik, menikmati kegiatan belajar tanpa ada perasaan tertekan. Kemudian merancang suasana ruangan yang berbeda. Memperbanyak interaksi dengan pesera didik untuk memancing pendapat dan argumen mereka, sehingga tumbuh keberanian dan rasa percaya diri dalam menyampaikan pendapat di depan orang banyak. Pendidik juga harus memiliki sifat humoris, hal ini akan menghilangkan kejenuhan, dan akan menimbulkan kedekatan emosional anatar pendidik dan peserta didik, sehingga apa yang disampaikan mudah diserap oleh peserta didik. $^{27}$

Disamping itu salah seorang pendidik menambahkan dalam sesi wawancara bahwa dalam penerapan metode pembelajaran, kami sebagai pendidik harus bijaksana dalam memilih materi yang relevan dengan kondisi dan latar belakang peserta didik, berupaya bahwa metode yang diterapkan dapat membangkitkan motivasi, minat, dan gairah belajar, serta dapat merangsang keinginan peserta didik untuk belajar lebih lanjut, dapat pula memberikan kesempatan kepada mereka untuk menciptakan hasil karya. Isi materi pelajaran yang

\footnotetext{
${ }^{26} \mathrm{Hj}$. Hany Tanua, Kepala Sekolah SMP Negeri I Kota Gorontalo, Wawancara, Tanggal 05 Juli 2019.

${ }^{27}$ Hasana U. Menu, Waka I Kepala Sekolah Bidang Kurikulum SMP Negeri I Kota Grontalo, Wawancara, tanggal 05 Juli 2019.
} 
dipilih harus mengandung persamaan dalam lintas kelompok, dan yang terpenting adalah Metodenya demokratis, yakni menghargai aspek-aspek perbedaan dan keberagaman budaya bangsa dan kelompok etnis, sehingga tercipta rasa saling toleran dan menghargai antar sesama. ${ }^{28}$

Dari hasil wawancara di atas, dapat penulis rumuskan bahwa Negara Indonesia yang besar dan pluralistik, yang ditandai dengan keberagaman dan keragaman budaya, agama, etnis, suku, adat, ras, dan antar golongan, maka pendidikan multikultural menjadi alat utama dalam memelihara dan menjunjung tinggi nilai nilai universal, dalam bingkai persatuan dan kesatuan bangsa indonesia. Berdasarkan amanat Undang Undang Dasar 1945 Psal 32 ayat 1 menyatakan. "Negara memajukan kebudayaan nasional indonesia di tengah peradaban dunia dengan menjamin kebebasan masyarakat dalam memelihara dan mengembangkan nilai nilai budayanya". untuk mendukung tercapainya tujuan pedidikan nasional, lembaga pendidikan baik dari jenjang sekolah dasar, menengah pertama, dan menengah atas, harus mampu mengimplemtasikan nilai nilai keragaman dalam setiap pembelajaran, sehingga sejak dini peserta didik mengerti dan memahami pentingnya sikap terbuka dalam memahami perbedaan, demi tercapainya kehidupan yang rukun dan harmonis.

\section{Pembelajaran Pendidikan Multikultural}

Pendekatan yang dapat dipakai dalam proses pembelajaran berbasis multikultural adalah pendekatan kajian kelompok tunggal (single group studies) dan pendekatan perspektif ganda (multiple perspektives approach) Pertama, pendekatan kajian kelompok tunggal adalah pendekatan yang dirancang untuk membantu peserta didik dalam mempelajari pandangan-pandangan kelompok tertentu secara lebih mendalam. Oleh karena itu, harus tersedia data-data tentang sejarah kelompok itu, kebiasaan, pakaian, rumah, makanan, agama yang dianut, tradisinya, dan kontribusi kelompok itu terhadap perkembangan musik, sastra, ilmu pengetahuan, politik dan lain-lain.

Selanjutnya menurut kepala sekolah bahwa pendekatan pendidikan Multikultural yang diterapkan di SMP Negeri 1 Kota Juli 2019 .

${ }^{28}$ Romy Rauf, Guru SMP Negeri I Kota Grontalo, Wawancara, tanggal 05

${ }^{29}$ Tilaar, H.A.R. Multikulturalisme:Tantangan Global Masa Depan dalam Transformasi Pendidikan Nasional.(Jakarta: Grasindo,2004), h. 45

94 | Manti S. Bempa 
Gorontalo adalah sebagaimana beliau jelaskan pada wawancara berikut ini:

Pendekatan multikultural yang diterapkan di SMP Negeri 1 Kota Gorontalo, dilakukan dengan pendekatan kontribusi, antara lain, mengenalkan beragam bentuk rumah dan baju adat dari etnis yang berbeda, mengajak peserta didik untuk mencicipi makanan yang berbeda dari berbagai daerah, dilakukan pada saat praktek tata boga, mendengar senandung lagu dari masing masing daerah pada saat pengembangan diri, menunjukan cara berpakaian yang berbeda baik dari suku bangsa, dan negara lain, pada saat hari hari besar, menunjukan tempat dan cara beribadah yang berbeda melalui pengembangan kerohanian, meminta peserta didik untuk menceritakan kebiasaan atau tatakrama dari masing masing suku, ras, dan entis. Inti dari penerapan metode ini, adalah menanamkan peserta didik bahwa manusia yang hidup disekitarnya, dan ditempat lain, serta di dunia ini sangat beragam. Sebenarnya semua nilainya sama. Dengan demikian peserta didik mulai mengerti, bahwa ada cara cara yang berbeda namun memiliki maksud dan tujuan dan nilai yang sama. Sehingga mereka dapat belajar untuk menerima perbedaan dengan proses rasa yang menyenangkan. Akhirnya peserta didik merasa bahwa perbedaan itu bukanlah masalah melainkan anugrah yang harus dipupuk dan dijaga. $^{30}$

Selanjutnya masih terkait pendekatan pembelajaran waka bidang kesiswaaan menjelaskan bahwa implementasi dari pendidikan multikultural, harus ditambahkan dengan pendekatan transpormasi, agar peserta didik pada jenjang SMP sudah mampu memiliki sudut pandang. Mereka mampu melihat konsep, isu, tema dan problem, dari berbagai prespektif dan sudut pandang etnis. Pada diri mereka sudah tertanam nilai nilai budayanya. Jadi mereka dapat berkompetisi dan beradu argumen serta mulai berani melihat sesuatu dari prespektif yang berbeda, sehingga dapat tumbuh dan tercipta sikap saling menghargai kebersamaan, dan cinta terhadap sesama yng dirasakan melalui pengalaman belajar. ${ }^{31}$

Kepala Sekolah menambahkan bahwa pembentukan pola pikir peserta didik, dapat dilakukan melalui metode pembentukan kelompok kelompok kecil dalam diskusi, kemudian diminta untuk berpendapat dan berargumen, selanjutnya pendidik menyodorkan sebuah isu yang hangat, dan diminta peserta didik untuk menganalisa

\footnotetext{
${ }^{30} \mathrm{Hj}$. Hany Tanua, Kepala Sekolah SMP Negeri I Kota Gorontalo, Wawancara, Tanggal 12 Juli 2019

${ }^{31} \mathrm{Hj}$. Fatmah Kaharu, Waka Kepala Sekolah SMP Negeri I Kota Gorontalo, Wawancara, Tanggal 12 Juli 2019
} 
dan mencari alternatif pemecahan terhadap masalah tersebut, tujuan pembelajaran ini adalah mendidik para peserta untuk mampu melakukan kritik sosial, dan mampu mengambil keputusan dan melaksanakan rencana alternatif yang lebih baik. ${ }^{32}$

Dari hasil wawancara di atas peneliti menyimpukan ada tiga substansi yang dilakukan oleh pihak SMP Negeri 1 Kota Gorntalo, dalam penerapan pendekatan pendidikan multikultural. Mulai dari pendekatan kontribusi, peserta didik dirangsang untuk mampu memahami berbagai perbedaan. Kemudian dalam pendekatan transpormasi, peserta didik diharapkan mampu merumuskan cara pandang yang positif terhadap perbedaan dan perkembangan yang ada. Lalu dalam metode kelompok, peserta didik mampu memahami dan menghargai perbedaan, serta bersama mencari solusi terhadap persoalan yang terjadi, dan bersama pula menciptakan kerukunan hidup yang lebih baik. Ketiga metode tersebut sangat tepat dalam mempersiapkan generasi abad 21, dengan landasan pemahaman yang komprehensif terhadap kemajemukan serta ampu menganalisa berbagai persoalan yang ada demi tercapainya kehidupan yang damai aman dan sejahtera. Setiap mata pelajaran memilik karakter yang berbeda dengan pelajaran lainnya.

Dengan demikian, masing-masing pelajaran juga memerlukan sarana pembelajaran yang berbeda pula. Dalam penyelenggaraaan pembelajaran guru pastinya memerlukan sarana yang dapat mendukung kinerjanya, sehingga pembelajaran dapat berlangsung dengan menarik. Dengan dukungan sarana pembelajaran yang memadai guru tidak hanya menyampaikan materi secara lisan, tetapi juga dengan tulisan dan peragaan sesuai dengan sarana prasarana yang telah disiapkan. Semakin lengkap dan memadai sarana prasarana yang dimiliki sebuah sekolah, akan memudahkan guru dalam melaksanakan tugasnya sebagai pendidik.

\section{Kesimpulan}

Langkah langkah evaluasi sistem pendidikan multikultural dalam pegembangan diri peserta didik di SMP Negeri 1 Kota Gorontalo, dengan menggunakan pendekatan model evaluasi Countenance Stake, yang memusatkan pada gejala atau fenomena yang dievaluasi sesuai K'13 Revisi 2017; mengumpulkan informasi yang didasarkan pada karakterisitik kompetensi dasar pada KI-1 dan KI-2 setiap mata pelajaran; Memasukkan data deskripsi pada

\footnotetext{
${ }^{32}$ Dra. Hj. Hany Tanua, M.Pd, Kepala Sekolah SMP Negeri I Kota Gorontalo, Wawancara Tanggal 12 Juli 2019 
framework matrik dalam hal ini menggunakan format penilaian; Processing analisis data pada framework matrik menggunakan standar penilaian; dan Membuat laporan hasil analisis.

Evaluasi Sistem Pendidikan Multikultural dalam pegembangan diri peserta didik di SMP Negeri 1 Kota Gorontalo, dilakukan untuk meningkatkan kesadaran diri peserta didik terhadap nilai-nilai keberagaman yang ada dilihat dari hubungan sesama peserta didik dengan menggunakan instrumen penilaian antar teman sesuai kurikulum 2013; hubungan pendidik dan peserta didik dengan menggunakan instrumen penilaian observasi/pengamatan dari guru; hubungan peserta didik dan lingkungan sosial, dengan menggunakan instrumen penilaian observasi/pengamatan.

\section{Daftar Pustaka}

Aly, A. Menggagas Pendidikan Islam Multikultural di Indonesia, Jurnal Ishraqi Vol.II No.1 Januari -Juli 2003.

Aly, Abdullah, Pendidikan Multikultural di Pasantren, Yogyakarta: Pustaka Pelajar, 2011.

Amri, Sofan, Pengembangan dan Model Pembelajaran dalam Kurikulum 2013, Jakarta: Prestasi Pustakarya, 2013

Ananda, Rusydi \& Tien Rafida, Pengantar Evaluasi Program Pendidikan, Medan: Perdana Mulya Sarana, 2017.

Anwar, Herson, Pendidikan Multikultural (Tinjauan Manajemen Lembaga Pendidikan Islam Pesantren dan Madrasah), "Irfani" Jurnal Manajemen Pendidikan Islam Volume 12 Nomor 1 Juni 2016.

Baidhawy, Zakiyuddin. Pendidikan Agama: Membangun Multikulturalisme Indonesia, dalam Pendidikan Agama Berwawasan Multikultural. Jakarta: PT Gelora Aksara Pratama, 2005.

Banks, James, Multicultural Eeducation: Historical Development, Dimension, and Practice. Review of Research in Education, 1993, http://awankboys.blogspot.com/2010/05/pendidikan multikultural. html diakses 18 November 2018

Daryanto, Evaluasi Pendidikan, Jakarta : Rineka Cipta, 2012.

Erwinsyah, Alfian, Model Penerapan ICT Untuk Peningkatan Kualitas Pembelajaran, "Tadbir" Jurnal Manajemen Pendidikan Islam Volume 4 No. 1 Februari 2016. 
Hanum, Farida, Pendidikan Multikultural Sebagai Sarana Membentuk Karakter Bangsa, Jurnal ,Universitas Negeri Yogyakarta, 2009.

Herlinawati, Dyah, Konsep Pendidikan Multikultural Henry Alexis Rudolf Tilaar. dan Relevansinya dengan Pendidikan Islam, ,Jurnal ,Universitas Negeri Yogyakarta, 2009.

Ladiku, Nilda S. Munirah, Pengembagan Sikap Keberagamaan Peserta Didik, "Al-Jauhari" Jurnal Studi Islam dan Interdisipliner Volume 4 No 2, Desember 2019.

Lukum, Astin, Evaluasi Program Pembelajaran IPA SMP Menggunakan Model Countenance Stake, Jurnal Penelitian dan Evaluasi Pendidikan Volume 19, No 1, Juni 2015.

Mahfud, C. Pendidikan Multikultural. Yogyakarta: Pustaka Pelajar, 2009.

Mahmudi, Ihwan, CIPP Suatu Model Evaluasi Program Pendidikan, Jurnal At-Ta'dib Vol. 6, No. 1, Juni 2011.

Maksum, Ali dan Luluk Yunan Ruhendi, Paradigma pendidikan Universal di Era Modern dan Post-Modernisme, Yogyakarta: IRCiSod, 2004.

Munirah, Nilda S. Ladiku, Pengembagan Sikap Keberagamaan Peserta Didik, "Al-Jauhari" Jurnal Studi Islam dan Interdisipliner Volume 4 No 2, Desember 2019.

Muqoyyidin, Wahyun, Andik, Membangun Kesadaran InklusifMultikultural Untuk Deradekalisasi Pendidikan Islam, Jurnal, Universitas Darul Ulum, Jombang: 2013.

Nugroho, Aji, Muhammad, Urgensi dan Signifikansi Pendidikan Islam Multikultural Terhadap Kompleksitas Keberagamaan di Indonesia, dalam At-Tarbiyah; Journal Of Islamic Culture And Education. Vol. 1, No. 2 Tahun 2016

Suryana, Yaya, Pendidikan Multikultural, Suatu Upaya Penguatan Jati Diri Bangsa, Surakarta:Pustaka Setia, 2015. 